\title{
Axenfeld anomaly
}

INSERM

\section{Source}

INSERM. (1999). Orphanet: an online rare disease and orphan drug data base. Axenfeld anomaly. ORPHA:98978

Axenfeld's anomaly is a rare cong enital ocular defect caused by anterior segment dysgenesis and is characterized by anteriorly displaced Schwalbes line and iris bands extending into the cornea. In contrast, Riegers anomaly (see this term) includes characteristic iris and pupil anomalies. 